\title{
Numerical study of building materials filled by PCM for thermal energy storage
}

Youcef OUsSama SOUCI - Laboratory of Numerical and Experimental Modelling of Mechanical Phenomena, University Abd El Hamid Ibn Badis of Mostaganem, Algeria • souci_youcef@yahoo.fr

SAmIR HOUAT - Laboratory of Numerical and Experimental Modelling of Mechanical Phenomena, University Abd El Hamid Ibn Badis of Mostaganem, Algeria

Érkezett: 2018. 04. 29. - Received: 29. 04. 2018. - https://doi.org/10.14382/epitoanyag-jsbcm.2018.23

\begin{abstract}
Phase change material (PCMs) is used to equilibrate the temperature fluctuation and to store energy in several practical application areas such as electronics, automobile industry and also buildings. In this paper, an example of the application of phase change material in the building application is investigated. The physical problem of phase change is solved by using a numerical study based on the finite element method. The PCM selected in this study, is incorporated directly within the building materials for improving its capacity of thermal storage. Two different building materials are selected according to their usual applying as construction materials for residential buildings. The numerical results have been checked and validated with an experimental model and the error is estimated.

The results reveal the potential of PCM in the enhancement on the thermal inertia of the wall and effectively reduced the fluctuation of the interior surface temperature. In addition, with the increasing filling amount of PCM, the thermal response of the building material will be more effective through improving its thermal insulation and stored more of energy as a latent heat. Keywords: Building materials, PCM, energy storage, finite element method

Kulcsszavak: Építôanyagok, PCM, energia tárolás, véges elemes eljárás
\end{abstract}

\section{Introduction}

As demand in thermal comfort of the buildings rises, the energy consumption is correspondingly increasing. For example, in Algeria, the energy consumption of buildings has increased by $22 \%$ the last three years. Housing and tertiary buildings are responsible for the consumption of approximately $43 \%$ of all energies [1].

At present, the thermal energy storage systems (TESS) are becoming more popular with regard to its incorporation in building materials, which in turn will reduce the dependence on fossil fuels for environmental and economic reasons [2]. The energy content in latent heat allows the PCM to transform its phase (from liquid to solid or vice versa) that permit it to store or release energy according to the required thermal loads [3]. Relying on the phase changing state, we note the three different cases by which the PCMs are characterized (solidsolid / solid-liquid / liquid-gas) [4]. Moreover, the solid-liquid phase changing is most suitable for the storage of thermal energy, where PCMs are clustered in three types: organic, inorganic and eutectic [5-7].

The applications of PCM can be extended to several disciplines such as medicine, sports and construction [8-9]. The integration of PCM in building materials such as concrete, ceramics, glass and hollow brick [10-16] is a way to enhance the storage capacity of building envelope and then to rationalize the use of renewable and non-renewable energies.

These studies have requested an improvement in thermal inertia, in order to store thermal energy [17]. The most effective method is using PCMs in both cooling and passive and active heating of the building.
The ways by which the PCMs are incorporated, namely the direct incorporation, immersion and encapsulation have been analyzed by Hawes and Feldman [18].

Soaresa et al [19], provided a comprehensive review on the previous research addressing the passive latent heat thermal energy storage systems with PCM in buildings and their related performance. The study covers different characteristics, thermal properties, and selection criteria of PCM. The experiments and the numerical modelling of heat transfer with PCM and different dynamic simulations of energy building with PCM are reported. Finally, the life cycle assessments, both environmental and economic, were discussed.

Castell et al [20], experimentally tested the PCM with two types of typical construction material. The study showed that using the PCM reduces the peak temperature by $1^{\circ} \mathrm{C}$ and the electrical energy consumption by $15 \%$. Alawadhi [21], one of the few researchers who studied numerically the thermal analysis of two-dimensional model of common building bricks with cylindrical holes integrated PCM to reduce the heat flow by storing energy from outdoor space in a hot climate during the day. This energy was retrieved during night time by solidification of PCM. The study focused on investigating different types of PCM at different melting temperatures, different PCM quantities at different brick's spatial locations. The study reported up to $17.55 \%$ savings in energy.

Many studies have investigated the use of PCM in buildings and showed that the PCM can remarkably improve the building energy performance. But few studies have examined the comparison between building materials when using PCM and its practical application. 
At the present paper, to determine the influence of the use of the thermal energy system in building applications, a numerical study based on the finite element method has been carried out. To reach this objective, two different construction materials which were usually used in Algeria have been selected. The purpose of this study is to evaluate the total energy storage of these two materials, when filled by PCM, by analyzing and comparing their energetic performance.

\section{Materials and methods}

\subsection{Material descriptions}

Two building materials filled by PCM are carried out. The first one (M1) is the hollow brick and the second material (M2) is the breeze block as shown in Fig. 1. The hollow brick used consisting of 8 internal empty holes which have a parallelepiped section $\left(3.5 \times 3.5 \mathrm{~cm}^{2}\right)$. The total dimensions of this material are thickness $=10 \mathrm{~cm}$, width $=20 \mathrm{~cm}$ and length $30 \mathrm{~cm}$. For the breeze block is consists of 6 parallelepiped holes $\left(7 \times 14 \mathrm{~cm}^{2}\right)$ and its total dimensions are thickness $=20 \mathrm{~cm}$, width $=50 \mathrm{~cm}$ and length $=20 \mathrm{~cm}$.
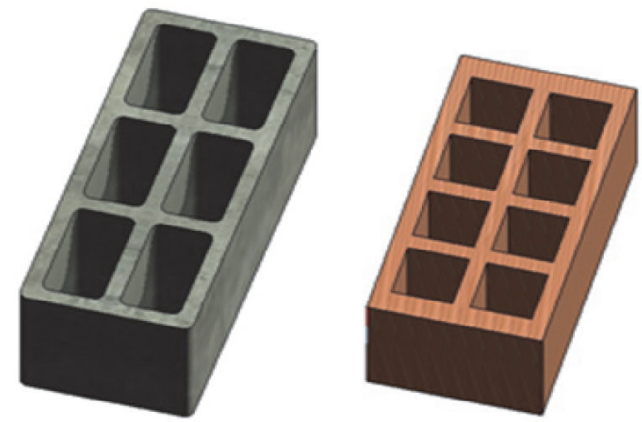

Fig. 1. Left: Hollow brick; Right: Breeze block

1. ábra Bal: üreges tégla, jobb: falazóblokk

The PCM selected and used in the present work is the organic paraffin $n$-octadecane with a phase change temperature of PCM at the main peak is $27.6{ }^{\circ} \mathrm{C}$ and the latent heat is about 243.5 $\mathrm{kJ} / \mathrm{kg}$ [17]. This PCM was chosen because of its compatibility with closed container made of plastic in order to prevent its leakage at the liquid state and also because they are considered non corrosive and are chemically inert. The thermo physical characteristics of hollow brick, breeze block and PCM are shown in Table 1.

\begin{tabular}{|c|c|c|c|}
\hline Material & $\begin{array}{l}\text { Density } \\
\left(\mathrm{kg} / \mathrm{m}^{3}\right)\end{array}$ & $\begin{array}{l}\text { Thermal Conductivity } \\
\qquad(\mathrm{W} / \mathrm{m} \cdot \mathrm{K})\end{array}$ & $\begin{array}{c}\text { Heat capacity } \\
(\mathrm{J} / \mathrm{kg} \cdot \mathrm{K})\end{array}$ \\
\hline PCM (solid) & 865 & 0.358 & 1934 \\
\hline PCM (liquid) & 780 & 0.148 & 2196 \\
\hline Hollow Brick & 1600 & 0.7 & 840 \\
\hline Breeze Block & 1300 & 1.05 & 648 \\
\hline
\end{tabular}

\subsection{Governing equations and boundary conditions}

In order to simplify the mathematical model, many assumptions are made in this numerical analysis:
- Heat transfer process across the building material with PCM is unsteady and is treated as a one-dimensional problem (because these building material represent elements of a wall which its thickness is smaller than the other dimensions).

- The PCM material used is pure, homogeneous and isotropic.

- All thermo-physical properties of the building materials were kept constant except the conductivity and specific heat of PCM may be different in the liquid and solid phases.

- The natural convection of the PCM during the melting process and the super-cooling effect during the freezing process can be neglected when the temperature

difference between the initial conditions and boundary is small [22].

- The interface layers between the building material and the PCM are homogeneous with perfect contact between them, which means that contact resistance is neglected.

- The surrounding radiation is neglected.

The transient enthalpy equation is given by Eq. (1):

$\rho \frac{\partial \mathrm{h}}{\partial \mathrm{t}}=\lambda \frac{\partial^{2} \mathrm{~T}}{\partial \mathrm{x}^{2}}$

For the Non-PCM layer, the enthalpy $(\mathrm{KJ} / \mathrm{kg})$ is given only by the sensible enthalpy as shown in Eq. (2) and for The PCM layer, the enthalpy $(\mathrm{KJ} / \mathrm{kg})$ is computed in Eq. (3) as the sum of the sensible enthalpy and the latent heat.

$\mathrm{h}=\mathrm{h}_{\text {ref }}+\int_{\mathrm{T}_{\text {ref }}}^{\mathrm{T}} \mathrm{C}_{\mathrm{p}} \partial \mathrm{T}$
$\mathrm{h}=\mathrm{h}_{\text {ref }}+\int_{\mathrm{T}_{\text {ref }}}^{\mathrm{T}} \mathrm{C}_{\mathrm{p}} \partial \mathrm{T}+f \mathrm{~L}$

Where $h_{\text {ref }}$ is the reference enthalpy at the reference temperature $\mathrm{T}_{\text {ref }}$, $\mathrm{f}$ is the liquid fraction and $\mathrm{L}$ is the latent heat of PCM $(\mathrm{KJ} /$ $\mathrm{kg})$. The liquid fraction of PCM is defined as:

$f=\left\{\begin{array}{lll}0, & \text { if } T<T_{m} & \text { (solid) } \\ 1, & \text { if } T>T_{m} & \text { (liquid) }\end{array}\right.$

Where $\mathrm{T}_{\mathrm{m}}$ is the melting temperature of PCM.

For both building materials with and without PCM, Eq. (5) is used to calculate the energy stored by unit of surface $E(t)$ :

$E(t)=\int_{0}^{t}\left(\varphi_{\text {in }, s}-\varphi_{\text {ext }, s}\right) d t$

$\varphi_{\mathrm{in,s}}, \varphi_{\text {ext,s }}$ are the inside and the outside surface heat flux, respectively.

The boundary condition at the indoor and the outdoor surfaces:

$-\lambda_{\mathrm{b}} \frac{\partial \mathrm{T}_{\mathrm{b}}}{\partial \mathrm{x}}=\mathrm{h}_{\mathrm{c}, \mathrm{j}}\left(\mathrm{T}_{\mathrm{j}}-\mathrm{T}_{\mathrm{j}, \mathrm{s}}\right)$

$\left\{\begin{array}{l}h_{c, j}=h_{c, i n}, T_{j}=T_{i n}, T_{j, s}=T_{i n, s} \quad ; x=0 \\ h_{c, j}=h_{c, e x t}, T_{j}=T_{e x t}, T_{j, s}=T_{e x t, s} ; x=w\end{array}\right.$

The numerical values of the convective heat transfer coefficient can be assumed as in [23] $\mathrm{h}_{c, \text { ext }}=20 \mathrm{~W} / \mathrm{m}^{2}{ }^{\circ} \mathrm{C}$ and $\mathrm{h}_{\mathrm{c}, \text { in }}=10 \mathrm{~W} / \mathrm{m}^{2}{ }^{\circ} \mathrm{C}$. 
At the building material/PCM interfaces:

$\lambda_{\mathrm{pcm}} \frac{\partial \mathrm{T}_{\mathrm{pcm}}}{\partial \mathrm{n}}=-\lambda_{\mathrm{b}} \frac{\partial \mathrm{T}_{\mathrm{b}}}{\partial \mathrm{n}}$

Where $\mathrm{n}$ is the coordinate normal to the surface of the PCM cavity.

\section{Numerical validation}

Before exhibiting the obtained results, the numerical code is validated by comparison with an experimental solution available in the literature [24]. The experimental setup depends on testing a hollow slab incorporated by PCM. The PCM selected is characterized by a melting temperature equal to $27^{\circ} \mathrm{C}$. At the bottom surface of the slab, a linear increasing is imposed in temperature of $20{ }^{\circ} \mathrm{C}$ to $35^{\circ} \mathrm{C}$ for one hour (Rate of rise $=1.25^{\circ} \mathrm{C} / \mathrm{h}$ ) and then maintains the temperature at 35 ${ }^{\circ} \mathrm{C}$ for 6 hours. Their top surface is in direct contact with the atmosphere of the laboratory room $\mathrm{T}_{\text {in }}=0{ }^{\circ} \mathrm{C}$.

A study on mesh type and size has been carried out for this validation. It has been selected a triangular mesh with an element number equal to 2428 and the convergence criterion for temperature used is $10^{-4}$.

Fig. 2 shows the comparison between our numerical results with the results that were obtained in the experimental on the variation in the temperature of the bottom and top surfaces of the slabs. For the validation study, the Maximum Error calculated by Eq. (8) is used to assess the difference between experimental and numerical results.

Maximum Error $(\%)=\max _{1.2 . n}\left\{\left|\frac{\mathrm{T}_{\exp }-\mathrm{T}_{\text {num }}}{\mathrm{T}_{\exp }} \times 100\right|\right\}$

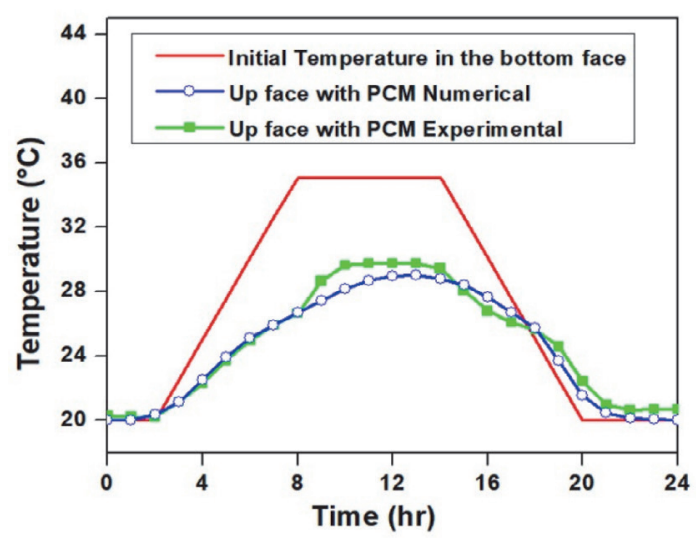

Fig. 2. Temperature at the interfaces of the floor panel

2. ábra Hömérséklet a födémpanel felületén

As shown in Fig. 2, the numerical result agrees well with the experimental measurements with the maximum error of (5\%). Three reasons can explain the slight discrepancy between simulation and experimental data. Firstly, the quality of the insulation material that has been used in the experiment to isolate the lateral faces of the slab is not perfect to provide the same performance as that used in the numerical simulation. Secondly, in the experimental study, it has been found that the melting temperature is not equal to the solidification temperature of the PCM. Thus, in the numerical study, this difference between both temperatures could create a sort of imprecision in the selection of the $\delta \mathrm{T}$ value (phase transition zone). Finally, the possibility that the effect of the natural convection in the experimental case is not neglected and it can be integrated into the liquid state of the PCM what is different from the hypotheses that have been taken in the simulation model.

\section{Results and discussion}

The test results about the influence of the PCM on the thermal storage capacity of two different building materials have been summarized in Figs. 3 to 5 .

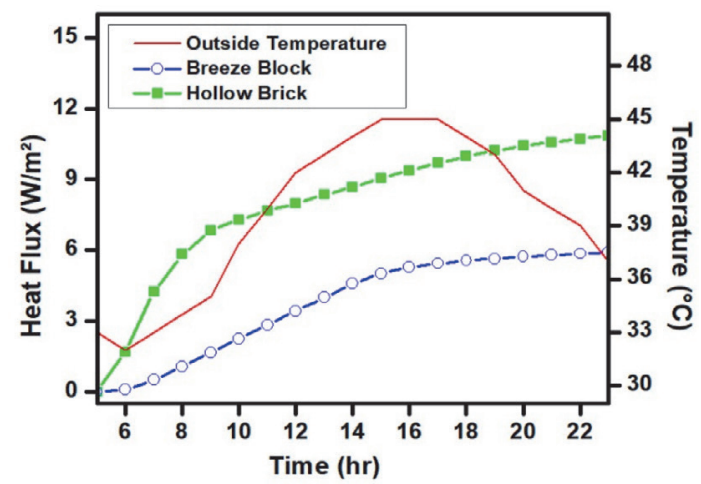

Fig. 3. Heat flux at the indoor surface for both materials with PCM 3. ábra Höáram mindkét PCM anyaggal kitöltött blokk esetén beltéri felületen

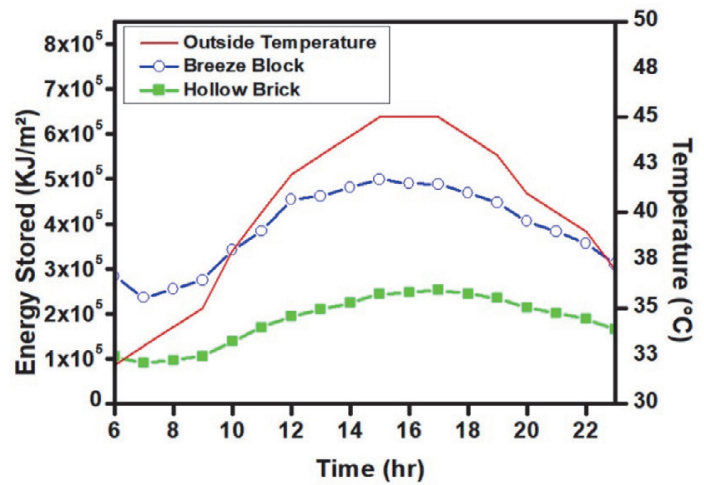

Fig. 4. Energy stored per unit of surface as a function of time 4. ábra Felületre vonatkoztatott hőtárolás az idö függvényében

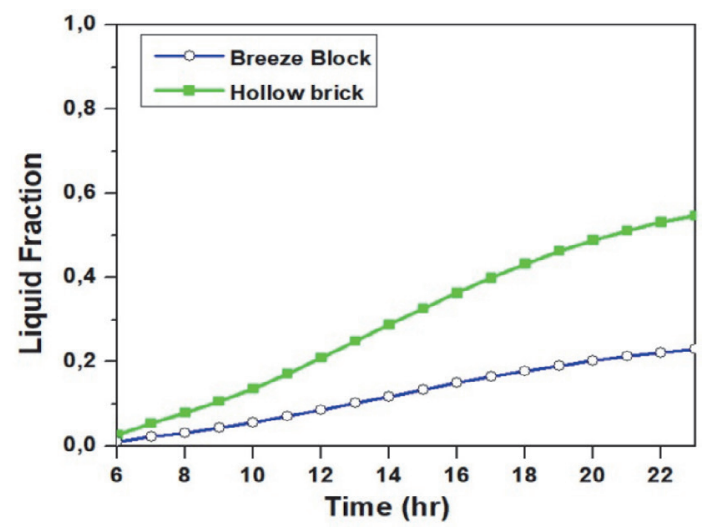

Fig. 5. Liquid Fraction for both materials with PCM

5. ábra Folyadék fázis mindkét PCM anyaggal kitöltött blokkra vonatkozóan 
The finite element method is utilized to solve the physical problem. For both building materials selected, it has been used a Free quadrilateral element to mesh the computational domain. The software used at this numerical study offers the possibility to configure an automatic mesh with different element sizes. The choice of the type of mesh is based on the study of the influence of the number of elements on two physical parameters namely the average temperature of model and the liquid fraction of PCM. The results of this study are shown in Table 2.

\begin{tabular}{lccccccc} 
& \multicolumn{2}{c}{$\begin{array}{c}\text { Number of } \\
\text { elements }\end{array}$} & \multicolumn{2}{c}{$\begin{array}{c}\text { Temperature } \\
\left({ }^{\circ} \mathbf{C}\right)\end{array}$} & \multicolumn{2}{c}{$\begin{array}{c}\text { Liquid } \\
\text { Fraction }\end{array}$} \\
\cline { 1 - 6 } Material & $\begin{array}{c}\text { Breeze } \\
\text { Block }\end{array}$ & $\begin{array}{c}\text { Hollow } \\
\text { brick }\end{array}$ & $\begin{array}{c}\text { Breeze } \\
\text { Block }\end{array}$ & $\begin{array}{c}\text { Hollow } \\
\text { brick }\end{array}$ & $\begin{array}{c}\text { Breeze } \\
\text { Block }\end{array}$ & $\begin{array}{c}\text { Hollow } \\
\text { brick }\end{array}$ \\
\cline { 1 - 6 } Fine & 305 & 160 & 27.78 & 29.09 & 0.232 & 0.549 \\
\hline Intermediate & 1000 & 276 & 27.79 & 29.06 & 0.229 & 0.547 \\
\hline Extremely fine & 6976 & 1375 & 27.79 & 29.03 & 0.228 & 0.543
\end{tabular}

Table 2. Effect of the mesh size on the temperature and the liquid fraction of PCM 2. táblázat Hálóméret hatása a hömérsékletre és a PCM folyadék fázisára

The observation of the results shows the independence of the number of meshes on the values of the temperature and the liquid fraction of PCM. Similarly, beyond a finer mesh, the increase in the number of elements becomes insensitive and it will not necessarily change the solution but it requires a longer calculation time. Therefore, after various mesh tests, it has adopted a Structured quadrilateral mesh with an element number equal to 800 for the hollow brick and 1000 element number for the breeze block.

The two materials selected subject to an external air temperature of a day time as an example of real conditions. Constant temperature is applied as the indoor air temperature $\mathrm{T}_{\text {in }}=25^{\circ} \mathrm{C}$.

As it is shown in Fig. 3, a comparison of the heat flux at the indoor surface between the two building materials is investigated. In the light of the results shown in this figure, the level of the heat flux obtained by the hollow brick is higher than that obtained with the breeze block. One of the significant reasons that lead to this result can be the difference between the PCM amounts inserted within both materials. The amount of PCM in the breeze block is about $83 \%$ larger than that used in the hollow brick due to the different geometries between the two materials. Therefore, the hollow brick-PCM system will not benefit a lot from its high latent heat because when a small quantity of PCM is used, this will leads to accelerate the melting/freezing process and making PCM most time in a deactivated mode. On the other hand, for the breeze block with PCM, most of heat will be stored as latent heat rather than as sensible heat due to the large energy needed by PCM in order to complete its phase change process. As a result, more energy will be absorbed by the material instead of being transmitted to the inner side.

Fig. 4 presents the quantity of heat per surface unit as a function of time, which is calculated by using Eq. (5). It can be seen that the thermal energy stored in the breeze block with PCM is larger than that stored in the hollow brick.

At the end of the day, it has been found that the energy stored as latent heat by the PCM placed inside the breeze block is about $2.29 \times 10^{6} \mathrm{KJ} / \mathrm{m}^{2}$. While, for the PCM inside the hollow brick, it has stored a small quantity of latent heat which is around $10^{6} \mathrm{KJ} / \mathrm{m}^{2}$.

This result is compatible with what has been mentioned above. As it is observed from the obtained values that as the amount of PCM increases, the demand to store more latent heat becomes important in order to complete the phase change process.

To aid in understanding these results in Fig. 4, it has been evaluated the liquid fraction as is shown in Fig. 5. It can be seen that more than $50 \%$ of the PCM inserted in the hollow brick has converted to the liquid state. In turn, only $25 \%$ of the PCM in the breeze block has changed its phase. This finding reveals that most of the energy is stored as a sensible heat in the breeze block with PCM due to the large amount of PCM that has been remained most of the time at its solid state. Thus, it has the opportunity to store more of latent heat and this leads to reduce the heat gain. Due to this fact, using a building material which is capable to contain a larger amount of PCM is more effective to weak the effect of outdoor temperature fluctuation on indoor thermal environment and that by enhancing its thermal insulation effect.

\section{Conclusions}

A numerical model was established to evaluate the potential of the thermal energy stored when it's applied in the building application. The proposed solution to achieve this is the incorporation of a phase change material in the construction elements. The numerical code is validated with an experimental model in the literature. It has been seen that the numerical results agreed well with the experimental results. Two different building materials are selected as an example to test its capacity of stored energy as a latent heat. Comparing the results from both materials, it is observed that the PCM addition, produces a reduction in the fluctuation of the heat flux at the inner surface of the breeze block more than the hollow brick. It has been explaining this result from the fact that there is a direct correlation between the increases in the amount of PCM and reduced heat flux at the inner surface.

It is observed that for the same test conditions, the breeze block with PCM stores 2 times more energy as a latent heat per unit surface than the hollow brick. This difference is due to the ability of PCM to complete its phase change rapidly. However, using a great quantity of PCM leads to delay the melt/solidification process so that the PCM could benefit more broadly from its potential to store the latent heat. Therefore, in practice and under similar conditions of this study, it is recommended to select a building material that can receive as much PCM as possible. This is because the increasing of the PCM amount has a positive effect on improving the thermal inertia of the building material. 


\author{
Nomenclature \\ $\mathrm{C}_{\mathrm{p}}$ : Specific heat capacity $\left(\mathrm{kJ} / \mathrm{kg} \cdot{ }^{\circ} \mathrm{C}\right)$ \\ $f$ : Liquid fraction \\ $\mathrm{h}$ : Enthalpy $(\mathrm{kJ} / \mathrm{kg})$ \\ $\mathrm{h}_{\mathrm{c}}$ : Convective heat transfer coefficient \\ $\mathrm{L}$ : Latent heat of fusion, $(\mathrm{kJ} / \mathrm{kg})$ \\ $Q_{s}$ : Solar flux radiation $\left(\mathrm{W} / \mathrm{m}^{2}\right)$ \\ $T:$ Temperature $\left({ }^{\circ} \mathrm{C}\right)$ \\ $t$ : Time (h) \\ $w$ : Thickness of wall (m)
}

\section{Greek symbols}

$\mathrm{k}$ : Thermal conductivity $\left(\mathrm{W} / \mathrm{m} \cdot{ }^{\circ} \mathrm{C}\right)$

$\rho$ : Density $\left(\mathrm{kg} / \mathrm{m}^{3}\right)$

\section{Subscripts}

\author{
b : Building material \\ $\mathrm{m}$ : Melting \\ $s$ : Surface \\ Ref : Reference \\ num : Numerical \\ exp : Experiment \\ in : Interior \\ ext : Exterior
}

\section{References}

[1] Ghedamsi, R. - Settou, N. - Gouareh, A. - Khamouli, A. - Saifi, N. Recioui, B. (2015): Estimating the energy consumption in building sector in Algeria using bottom-up mode, in: IEEE 16th International Renewable Energy Congress (IREC), May 2015, https://doi.org/10.1109/IREC.2015.7110942

[2] Dincer, I. - Rosen, M. (2002): Thermal Energy Storage - Systems and Applications. John Wiley and Sons.

[3] Diaconu, M. - Cruceru, M. (2010): Novel concept of composite phase change material wall system for year-round thermal energy savings. Energy and Buildings. Vol. 42, No. 10, October 2010, pp. 1759-1772. https://doi.org/10.1016/j.enbuild.2010.05.012

[4] Sharma, A. - Tyagi, V. V. - Chen, C. R. - Buddhi, D. (2009): Review on thermal energy storage with phase change materials and applications. Renewable and Sustainable Energy Reviews. Vol. 13, No.2, February 2009, pp.318-345. https://doi.org/10.1016/j.rser.2007.10.005

[5] Abhat, A. (1983): Low temperature latent heat thermal energy storage: Heat storage materials. Solar Energy. Vol. 30, No. 4, pp. 313-32. https://doi.org/10.1016/0038-092X(83)90186-X

[6] Lorsch, H. G. - Kauffman, K. W. - Denton, J. C. (1976): Thermal energy storage for heating and air conditioning: future energy production system. Heat Mass Transfer Proceedings. Vol. 1, January 1976, pp. 69-81.

[7] Lavinia, S. - Angela, P. - Paula, U. - Oana, G. (2014): Review on phase change materials for building applications. Leonardo Electronic Journal of Practices and Technologies. Vol. 13, No. 25, December 2014, pp. 179-194

[8] Jones, B. - Hsieh, K. - Hashinaga, M. (1986): The effect of air velocity on thermal comfort at moderate activity levels. ASHRAE Transactions. Vol. 92, 1986, pp. 761-769.

[9] Mondal, S. (2008): Phase change materials for smart textiles-an overview. Applied Thermal Engineering. Vol. 28, No. 11-12, August 2008, pp. 15361550. https://doi.org/10.1016/j.applthermaleng.2007.08.009

[10] Schossig, P. - Henning, H. M. - Gschwander, S. - Haussmann, T. (2005): Micro-encapsulated phase-change materials integrated into construction materials. Solar Energy Materials and Solar Cells. Vol. 89, No. 2-3, November 2005, pp. 297-306.

https://doi.org/10.1016/j.solmat.2005.01.017

[11] Farid, M. M. - Khudhair, A. M. - Razack, S. A. K. - Al-Hallaj, S. (2004): A review on phase change energy storage: materials and applications. Energy
Conversion and Management. Vol. 45, No. 9-10, Jun 2004, pp. 1597-1615. https://doi.org/10.1016/j.enconman.2003.09.015

[12] Raabe, J. - Tzvetkov, G. - Flechsig, U. - Böge, M. - Jaggi, A. - Sarafimov, B. - Vernooij, M. G. C. - Huthwelker, T. - Ade, H. - Kilcoyne, D. Tyliszczak, T. - Fink, R. H. - Quitmann, C. (2008): PolLux: a new facility for soft X-ray spectromicroscopy at the Swiss Light Source. Review of Scientific Instruments. Vol. 79, No.11, November 2008, pp. https://doi.org/10.1063/1.3021472

[13] Oliver, A. - Neila, F. - García, A. (2010): Caracterización térmica de placas de yeso con material de cambio de faseincorporado. Informes de la construcción. Vol. 62, No. 519, 2010, pp. 55-66.

https://doi.org/10.3989/ic.09.036

[14] Khudhair, A. M. - Farid, M. M. (2004): A review on energy conservation in building applications with thermal storage by latent heat using phase change materials. Energy Conservation and Management. Vol. 45, No. 2, January 2004, pp. 263-275. https://doi.org/10.1016/S0196-8904(03)00131-6

[15] Bentz, D. - Turpin, P. R. (2007): Potential applications of phase change materials in concrete technology. Cement and Concrete Composites. Vol. 29, No. 7, August 2007, pp.527-532. https://doi.org/10.1016/j.cemconcomp.2007.04.007

[16] Alawadhi, E. M. (2008): Thermal analysis of a building brick containing phase change material. Energy and Buildings. Vol. 40, No. 3, 2008, pp. 351-357. https://doi.org/10.1016/j.enbuild.2007.03.001

[17] Khudair, A. M. - Farid, M. M. (2007): A review on energy conservation in building applications with thermal storage by latent heat using phase change materials. Energy Conversion and Management. Vol. 45, No. 2, January 2007, pp. 263-275. https://doi.org/10.1016/S0196-8904(03)00131-6

[18] Hawes, D. - Feldman, W. D. (1992): Absorption of phase change materials in concrete. Solar Energy Materials and Solar Cells. Vol. 27, No. 2, July 1992, pp. 91-101. https://doi.org/10.1016/0927-0248(92)90112-3

[19] Soaresa N. - Costab J. J. - Gaspar A. R. - Santos P. (2013): Review of passive PCM latent heat thermal energy storage systems towards buildings' energy efficiency, Energy and Buildings. Vol. 59, No. 59, April 2013, pp. 82-103. https://doi.org/10.1016/j.enbuild.2012.12.042

[20] Castell, A. - Medrano, M. - Perez, G. - Cabeza, L. (2010): Experimental study of using PCM in brick constructive solutions for passive cooling, Energy and Buildings. Vol. 42, No. 4, April 2010, pp. 534-540. https://doi.org/10.1016/j.enbuild.2009.10.022

[21] Alawadhi, E. (2008): Thermal analysis of building brick containing phase change material, Energy and Buildings, Vol. 40, No. 3, 2008, pp. 351-357. https://doi.org/10.1016/j.enbuild.2007.03.001

[22] Joulin, A. - Younsi, Z. - Zalewski, L. - Lassue, S. - Rousse, D. R. - Carvot, J. P. (2011): Experimental and numerical investigation of a phase change material: thermal-energy storage and release. Applied Energy. Vol. 88, No.7, July 2011, pp. 2454-62. https://doi.org/10.1016/j.apenergy.2011.01.036

[23] Lamberg, P. - Lehtiniemi, R. - Henell, A. M. (2004): Numerical and experimental investigation of melting and freezing process in phase change materials storage, International Journal of Thermal Sciences. Vol. 43, No. 3, March 2004, pp. 277-287. https://doi.org/10.1016/j.ijthermalsci.2003.07.001

[24] Karim, L. - Bontemps, A. - Royon, L. (2013): Thermal energy storage and release of a new component with PCM for integration in floors for thermal management of buildings. Energy and Buildings. Vol. 63, August 2013, pp.29-35. https://doi.org/10.1016/j.enbuild.2013.03.042

$\underline{\text { Ref.: }}$

Souci, Youcef Oussama - Houat, Samir: Numerical study of building materials filled by PCM for thermal energy storage Építőanyag - Journal of Silicate Based and Composite Materials, Vol. 70, No. 4 (2018), 123-127. p. https://doi.org/10.14382/epitoanyag-jsbcm.2018.23 